\title{
Film as Media of Religious Dialogue: The Reception of Three Indonesian Contemporary
}

\section{Films}

\author{
Latifah \\ CCFS-Brawijaya University, East Java \\ email:efi_latifah@yahoo.com
}

\begin{abstract}
The paper examines the audience's response in consuming of religious representation in three Indonesian contemporary films: Ayat-Ayat Cinta (Verses of Love), 3 Doa 3 Cinta (3 Wishes 3 Loves), and Perempuan Berkalung Sorban (Woman with a Scarf Around her Neck). By examining the audience's response in media, particularly through electronic delivery, the paper shows that the public dispute of the Islam representation in this film serves as communication media of religious dialogue. The examination of audience's response on those three films illuminates the various impacts of Islamic film label embedded in their cinematic representation. Islamic film can be a profitable trademark since it gives more reasons to attract audience than entertainment motive does. Representation of religion analogue to religious teaching and practice creates religious film as media for religious dialogue between people, state, the faith communities, and film makers.
\end{abstract}

\section{Keywords:}

Film, Representation, and Religious-dialogue

\section{Introduction}

One day in February 2008, I was sitting in the lobby of a large classic cinema in Jakarta with hundreds of people waiting for a film to play: Ayat-Ayat Cinta. We had to wait for the next show because we could not get tickets yet. Perhaps, it sounds like an average day at the cinema, but for me, having watched films in that cinema before, something seemed 
very different. It appeared that there was not only the "regular audience", such as young people who stood in line to buy the movie tickets, but also an "extraordinary audience", including a household with all of its family members and neighbors, or jamaah pengajian (Islamic congregation "club"). As well, there were many groups of Muslim youth "clubs" who appeared to be entering the cinema for the first time. They seemed unfamiliar with the procedure at the cinema. Their behavior was also more various than the "regular audience". This unusual audience demonstrated their Islamic identity by their behavior and appearance. Many women, old and young, wore jilbab (headscarf). Young men used "baju koko", a typical Islamic activist cloth. Some of them passed the time by listening to Islamic songs or nasyid while waiting for the movie. Meanwhile, others used their time to do drikir (repetitively reciting God's name) even though they were in a cinema, which is identified as"secular entertainment".

The phenomenon of Ayat-Ayat Cinta has been successfully breaking the boundaries of "secular" and "profane" public spaces. In Indonesia, the cinema has been identified as un-Islamic activities and even pornography. People easily receive such impressions from observing erotic film posters in front of the cinema. Cinema's disturbing image is also emphasized by the widespread belief that cinema is a place for couples "enjoying the darkness". Besides "semi-blue" films, Indonesian cinema is also identified with horror films which are viewed as blasphemous because they go against the Islamic principle of oneness of God (taubid). In short, this negative image makes the cinema unpopular among many religious groups in Indonesia since it is seen as something offensive to Islamic morality and taubid. In addition, in regard to the Islamic conception of art, many Muslims cite a certain hadith of an Islamic source of teaching, which says that man will be punished on judgment day for creating a picture of life since the only creator is God. Thus, many Muslims in Indonesia still believe that film is a "secular" product, and the cinema has been categorized in 
binary opposition to sacred public spaces such as mosques.

The penetration of a "sacred" element into a profane sector has impacted the dispute over public spaces at a time when the state is losing the kind of control it had exercised in the pre-reformation era (i.e., during Soeharto 's New Order regime). As described in the study by Salam and Budiyanto (2005), the study on Islamic songs (nasyid) and television drama trends, Muslims have a new attitude toward public spaces because of their disappointment to the New Order administration. Counterculture ideology discourses have also been provoked by the impact of global issues, such as $9 / 11$, even though the willingness to fight "the infidel Western" powers is not a new phenomenon but was already evident in the colonial era.

Nevertheless, the cultural struggle of Muslim within popular culture arena does not mean Islam versus non-Islam or Islam versus West since Muslim is not a single entity, "Contemporary Islam is marked by plurality, a multi-centered political orientation, and a fierce ideological battle for dominance in the nation (Heryanto 2008, 20). What is more, despite its religious identity politics, economic motif cannot be overlooked regardless their effectiveness as missionary means. Looking at a phenomenon of popular culture in broader context beyond its close reading is a requirement to assess its production and consumption satisfactorily, as Heryanto (2008, 4) advised. In line with Heryanto, Bruner (Heider 1994, 164) emphasized how the variety of audience background influences the interpretation and the impact of film. In this sense, he suggested the importance of audience studies in the study of Indonesian cinema.

Henceforth, this paper will illustrate the audience's response including governmental, religious, and social institutional besides individual opinions to representation of Muslim in Ayat-Ayat Cinta (Verses of Love), 3 Doa 3 Cinta (3 Wishes 3 Loves), and Perempuan Berkalung Sorban (Woman with a Scarf Around her Neck). These films are chosen mainly 
because of their coeval as contemporary Islamic films produced in postSoeharto era when Islam's voice has gained more significance in political identity contestation as mentioned above. It contained Islamic missionary message with similar setting which is Islamic educational institution, either local, pesantren (Islamic residential school) in Java, or global, $\mathrm{Al}$ Azhar University in Cairo, Egypt. Regardless their likeness, the films has attracted a range of response in line with the heterogeneous Indonesian society. In this context, it is useful to examine the audience's response in media, particularly through electronic delivery. The paper will show the public dispute of the Islam representation in this film serves as media communication of religious dialog as Kadir (2009) assumed.

As Nugroho (2005, 224-225) points out that film proves its meaning as humanistic dialog media to show the complexity of Islamic world and to observe world's perspective to Islam, Islamic state, and stereotype of Islam and terrorism. He observed that the improvement of Islam image in worldwide cinema is as not merely white and black life, as seen in $A$ Fond Kiss, directed by Ken Loach (2004). The film told a story about culture clash of a third generation of Pakistani Muslims in Glasgow. Beside the norm change, film with Islamic community as the theme also depicts the specific subject matter about people's life power, especially children of refugee, and women's role in religion. However, Nugroho evaluates that Islam portrayal in Asian film has not gotten particular appreciation in world festival circuit. In his opinion, propaganda film with their formal and dogmatic symbolic dominates Asian film thus it loses its value and the potential as media dialog. The discussion on people's response to contemporary Indonesian Islamic film provides an answer to Nugroho's challenge to serve film as a mean of dialog through appreciation and critical creation. Furthermore, in Southeast Asian studies context, the analysis of contemporary Indonesian film is important as an attempt to give meaning to Southeast Asia as culture area (Evans 2002). In this way, 
the Southeast Asian community achieves existence by defining its own identity through cultural products and representation. Indonesian films are described as a part of third world cinema in Fredric Jameson's theory of "national allegory". Zhang $(1994,30)$ quotes Jameson:

Those [Third World] texts, even those narratives which are seemingly private and invested with a properly libidinal dynamic, necessarily project a political dimension in the form of national allegory: the story of the private individual destiny always an allegory of the embattled situation of the public Third World culture and society.

Because Islam is regarded as a guiding force in every aspect of life and film in local Indonesian contexts, the study of Indonesian Islamic films is important for understanding social changes and religious debates within Southeast Asia (Bowen 2003, 44-47). In order to get a comprehensive pattern of audience respond and predilection on Islamic film, this paper will be conducted mainly in three sections based on the chronologically launching time: Ayat-Ayat Cinta (2008), 3 Doa 3 Cinta (2008), and Perempuan Berkalung Sorban (2009).

\section{Ayat-Ayat Cinta}

In spite of its long trajectory, Indonesian Islamic film first came to public attention through the phenomenon of Ayat-Ayat Cinta. This Indonesian blockbuster film is based on the best-selling novel written by Habiburrahman El Shirazy, who was born in Semarang, Java in 1976 but was an alumnus of the renowned university Al-Azhar, Cairo, Egypt. Released in January 2007 and played during April 2007, the film successfully attracted more than three million viewers. In addition, it was successfully launched in abroad, particularly Singapore and Malaysia (wikipedia.org, April 15, 2010). It was a historic achievement in the Indonesian cinema industry. However, market-oriented goals were a first consideration of the producers, Dhamoo Punjabi and Manoj Punjabi from MD Pictures, 
a well-known electronic cinema conglomerate. With production costs of $\$ 1.5$ million, Ayat-Ayat Cinta offered a magic formula for religious films which was imitated by many Islamic films that followed: love and piety.

Taking a chance to share the spotlight with the popular culture fandom, President Susilo Bambang Yudhoyono and top government officials courted media's attention by watching the film with his family and eighty foreign ambassadors and diplomats. "I had to wipe my tears several times. It drives home the message," he commented dramatically (mobile. reuters.com, April 15, 2010).

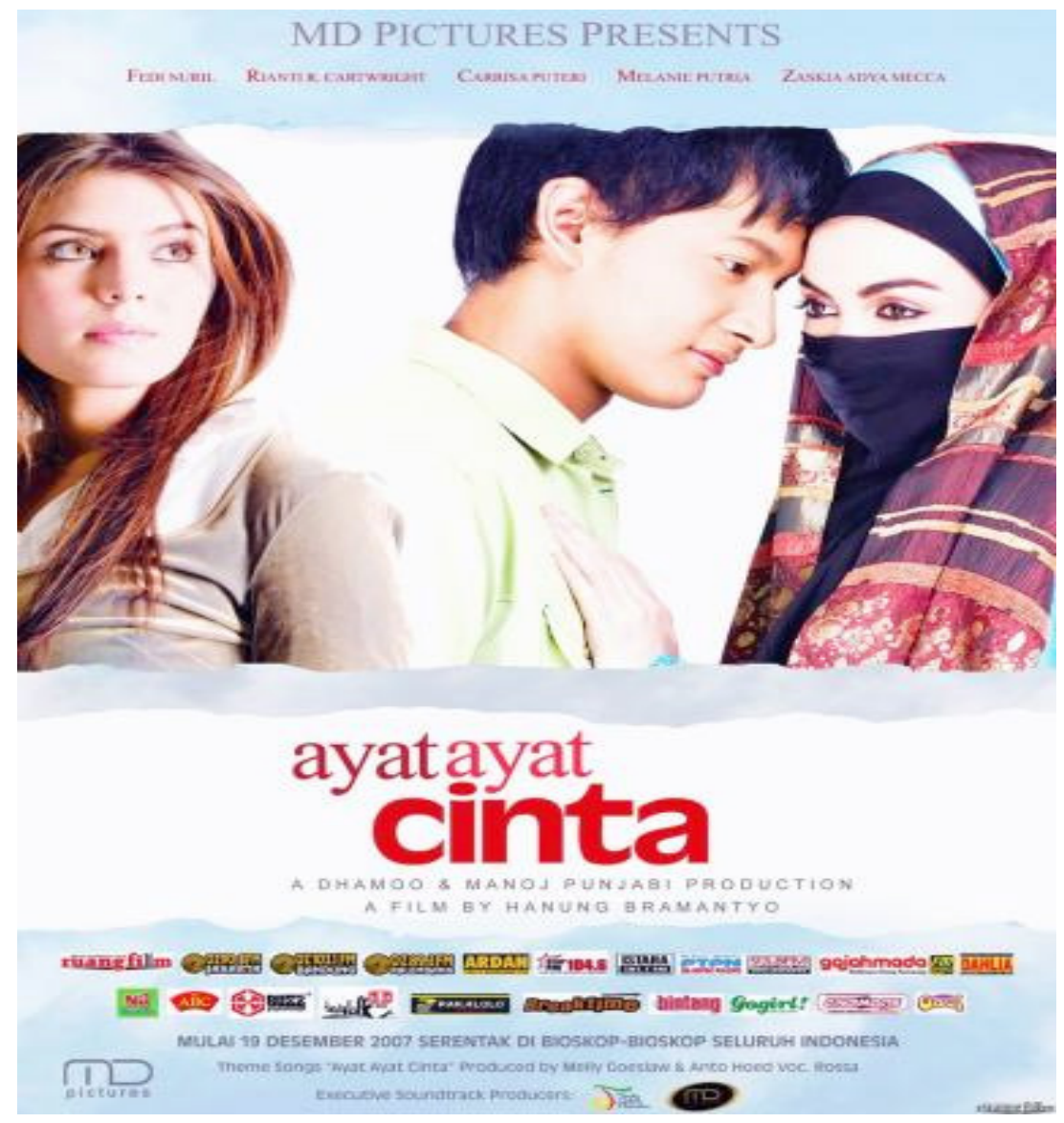

Film Poster of Ayat-Ayat Cinta

DINIKA, Volume I, Number 3, September - December 2016 
One of the factors that contributed to the film's booming in the market was the success of the novel associated with it. By December 2007 before the film was launched, the novel Ayat-Ayat Cinta had reached three hundred thousand copies in thirty reprints, a spectacular number for a best-selling book in Indonesia. Before being printed as a novel, the first version by Habiburrahman El Shirazy was published as a serial in a daily newspaper, Republika.

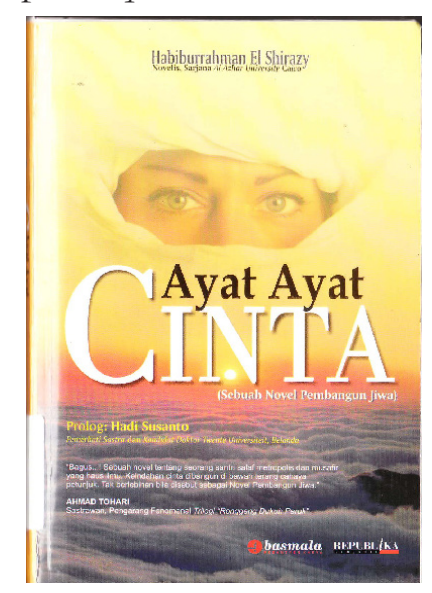

Older edition of Ayat-Ayat Cinta

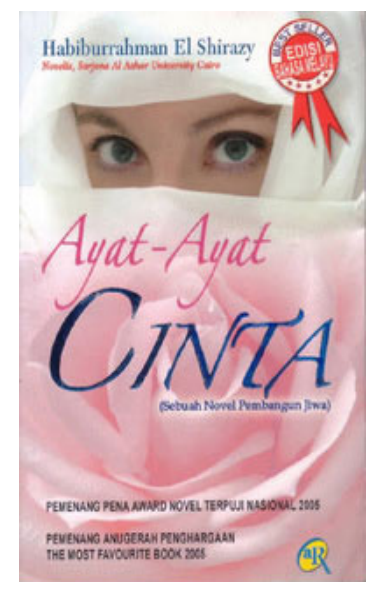

Newest edition of Ayat-Ayat Cinta

By claiming that his novel was sebuah novel pembangun jiwa "a Novel for Soul Development", El Shirazy indicates that this is a missionary novel, a point reinforced by its title Ayat-Ayat "verses" which refers to verses of the Islamic holy book, Al-Qur'an. However, the romanticism of the novel was also another major factor of its attractions. The author explicitly stated that the novel belongs to the love story genre, as indicated by the title Cinta "love". Accordingly, the main theme of AyatAyat Cinta is a love story about Muslims based on Qur'anic verses that invokes the spirit of God. In this sense, an audience, Anneezsa, comments that through the love relationship in Ayat-Ayat Cinta, Islamic view as a life guidance, particularly gender relationship arrangement is depicted, "I think... ayat-ayat cinta is a quite good film because from that film we 
can learn the islamic way of the relationship between man and woman" (thejakartapost.com, April 15, 2010). However, in his comment, Nauval Yazid, a JiFFest (Jakarta International Film Festival) 2009 programmer, make a clear distinction between Islam as background and the religious spirit of the film. Thus, as Da Vinci Code, Ayat-Ayat Cinta is not a religious film. He argues that in order to be considered as a religious film, a film "has a storyline which unfolds in a religious context, driven by religious teachings" (Jakarta Post, February 03, 2008).

Even though the writer and the director of Ayat-Ayat Cinta recognize the film as a non- religious film, public opinion is formed by its Islamic identification regarding to its backdrop and the elements of the story rooted in Islamic tradition. The value that Islam as a way of life and guidance in all aspects of life based on the Qur'an and Hadith has been the base of people judgment to the film. The multilayer interpretation of religious teaching and tradition contributes to the dynamism of audiences. The meaning of the film as a missionary (dakwah) medium for people is proved through the people's attention to the persona (actor) and the performance (acting) arrangement since "who is talking what" and "how to" deliver the message are very important considerations in dakwah. Moreover, Islam also has strict behavioral guidelines particularly with regard to gender relationship and related symbolism.

Most people view that AAC is a way of preaching through film. There is nothing wrong with it. I would say that I do not agree with the view. If it is a way of preaching, the message should be pure. The scene as you can see in electronic cinema or sluttish film should be omitted because they are not mahram (Immediate/close relative).

In my opinion, the cast of the pure religious film for preaching should be ikhwan and akhwat (Man or woman who committed to Islam).

And intimate scene should be thrown away.

If the cast is easy, the film will be low in quality. In film they said, to 
have a boy or girlfriend is prohibited, but outside the screen, they act conflicted with their saying.

( $\mathrm{h} \mathrm{t} \mathrm{t} \mathrm{p} \mathrm{:} \mathrm{/} \mathrm{/} \mathrm{t} \mathrm{r} \mathrm{a} \mathrm{n} \mathrm{s} \mathrm{l} \mathrm{a} \mathrm{t} \mathrm{e.g} \mathrm{o} \mathrm{o} \mathrm{g} \mathrm{l} \mathrm{e.co.id} \mathrm{/}$ translate? $\mathrm{hl}=\mathrm{en} \& \mathrm{sl}=\mathrm{id} \& \mathrm{tl}=\mathrm{en} \& \mathrm{u}=\mathrm{http} \% 3 \mathrm{~A} \% 2 \mathrm{~F} \% 2 \mathrm{Fwww}$. gaulislam.com $\% 2$ Ffilm-ayat-ayat-cinta-itu\&anno=2)

The religious sentiment provoked the similar reactions expressed even though she has not watch the film.

Up to now I have not read that novel or the film. I bought it, but I gave it as present to someone else, he... he... For the film, it seems that the aim and the content are already good. Presenting an Islamic love drama, I hope the Indonesian young generations will have the awareness in their social intercourse. However, the unIslamic scene such as holding hand should be unrepresented. Even though in the film they are marriage, in real world they are mabram. Thus, this kind of the scene should be omitted, not censored the scene which causes the value of preaching (translate.google.co.id, April 15, 2010).

Beside the objection to the cast and the acting which are seen as contrast to syariah, the more resistance is directed to the storyline and its gap with the spirit of dakwah. Conjunct with the characteristic differentiation between film and novel, director made some adaptations, particularly the story. In fact, the adaptation is made not merely for translating written text into screenplay, but also serving as the ideology expression of the director which might be different from the novel. The adaption can be interpreted as an attempt to reduce the image of Islamic conquers towards others. This way, the image of Islam as an inclusive religion is promoted. As a missionary novel, Ayat-Ayat Cinta tends to have the spirit of Islam as "a single truth", exclusive. Nevertheless, the targeted audience of the film is larger than the novel because the cost of the film production is much more than the novel publication. Therefore, even though it is a religious film, the producer tries to gain as much as possible of audience so that the massage of the film cannot be too narrow. This factor then combined with pluralistic fact of Indonesian society. 
One of the significant reductions in the film is the explicit image of some non-Muslims who convert to Islam. In the novel, the author described obviously how Alicia, an American journalist who was helped by Fahri before, finally converted to Islam. Her decision to convert to Islam was influenced much by her discussion with Fahri. In the same manner, the image of "Islamic conquering" is reduced by visual language; as mentioned before, when Maria is stating her syabadat that implies her conversion to Islam, the camera does not show Maria's -face, otherwise it focuses on Aisha who was crying ; giving more emphasize on the psychological effect of polygamy. At the beginning of the film, it depicts the friendship between Fahri and Maria, while in the novel it more explores the first meeting of Fahri and Maria that emphasizes the difference of religious identity between them through their dialogues. In the film, their religious difference is softened by the symbol of Christianity in Maria's hand. In short, the director of Ayat-Ayat Cinta makes use of visual language and adaptation of story so that it can be considered more suitable with "local" spirit represented by Hanung Bramantyo, the director with his "local" religious educational background, in opposition to Habiburahman El Shirazy, with his Middle East educational background.

On the other hand, the director's effort in eliminating the polemic because of the Islamic inclusive image has triggered another polemic by indicating the fear to reveal the truth about Islam, "Tak Berani Suarakan Islam", and creating misconception about pluralism (gaulislam.com, $15 / 04 / 2010)$. In addition, the director's strategy in softening the image of Islam is accused mainly based on market oriented consideration which makes hazy the basic principle of Islam. Da'wah should be conducted ideologically. Advancing Islam is not through the film which exploits the wealth of the Muslims only for the interests of the cursed bourgeoisie.

Despite the negative response regarding to misrepresentation of syariah, figh, and taubid, the film is also considered successful in representing 
the value of Islam related to family law and the conduct of man and woman relationship. Unlike the issue of religious convert, the director has the courage to present the polemic issue on polygamy and taaruf, which is still uncommon practice in Indonesia. In a way, the film can be interpreted as a counter global stereotype on polygamy which considered it as a patriarchal implementation. The film elucidates that polygamy also has religious motif, not only a result of male sexual driven. “...not all of the elements of the film is not correct. There are also the truthful aspects, such as polygamy and the rules of ta'aruf, ${ }^{1}$ about patience and sincerity" (gaulislam.com, April 15, 2010). The film has convinced the audience that in a marriage with ta'aruf and polygamy, the primarily base of man and woman relationship is sincerity to worship God; a realization of piety by accepting God's command.

Nonetheless, the director seems to anticipate the bigger polemic by expanding the story about polygamy to give deeper illustration about the impact of polygamy. In the novel, the dilemma of polygamy is just finished by extinguishing Maria, the second wife. This easy way out lessens the quality of novel since it is considered as deux at machina. In the film, even though at last Maria passed away as told in the novel, the story is lengthened. Maria experienced a longer polygamy life before she passed away. The experiences show that polygamy life is not easy even when Islam allows it. Polygamy which is often seen as a solution in fact creates bigger problem for the whole member of family.

However, it does not mean that the polygamy content in AyatAyat Cinta is polemic free from both sides. For the pro-polygamy side, the film is seen as a corruption of Islamic teaching since it features the bad impact of polygamy that is embedded in Islamic tradition. There is a concern about the impact of the film that will increase anti-polygamy

1 To match up the bride and groom-to be to know further their personality before marriage. Ta'aruf is differentiated with pacaran (dating) since the restricted man and woman relationship in ta'aruf. 
among akhwat (gaulislam.com, 15/04/2010). On the other hand, the contpolygamy side evaluated the film as legitimizing the polygamy based on man superiority over woman. However, the dispute on polygamy issue does not only involve Muslim, but also non-Muslim, as expressed in http://jephman.wordpress.com/2008/03/24/ayat-ayat-cinta/ in which they do not only judge polygamy as exclusively Islam's "bad habit", but also reflects it on their religious and ethnic tradition. What is more, the review about audience's response on polygamy issue also can be conducted intertextually since the comments are expressed through many creative ways, particularly comical manner as follows:

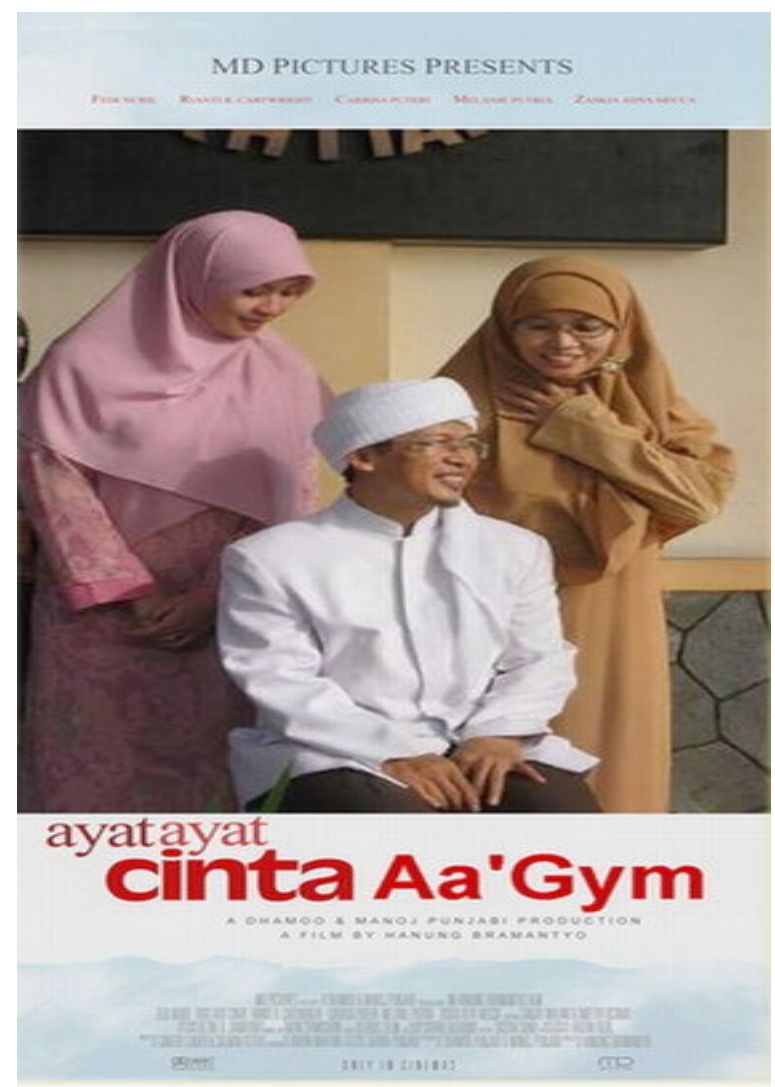

"The Real Ayat-Ayat Cinta" (alvahendi.files.wordpress.com, March 2008)

DINIKA, Volume I, Number 3, September - December 2016 


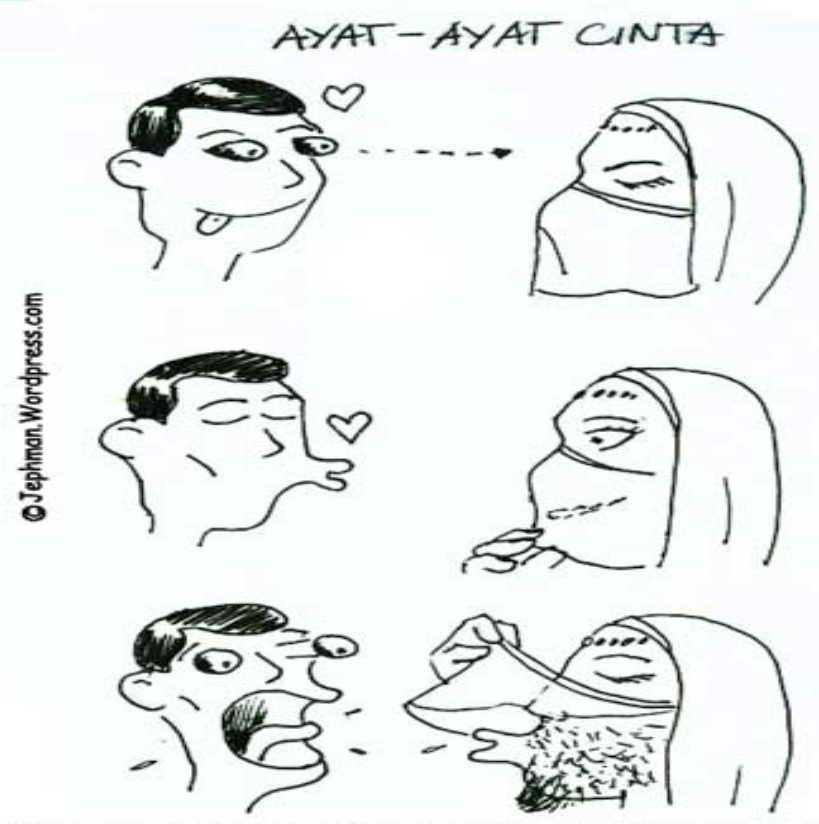

25 Hai suami, kasihilah isterimu sebagaimana Kristus telah mengasihi jemaat dan telah menyerahkan diri-Nya baginya

28. Demikian juga suami harus mengasihi isterinya sama seperti tubuhnya sendiri: Siapa yang mengasihi isterinya mengasihi dirinya sendiri.

29 Sebab tidak pernah orang membenci tubuhnya sendiri.

tetapi mengasuhnya dan merawatimya, sama seperti Kristus terhadap jemaat,

so sebab itu laki-laki akan meninggalkan ayahnya dan ibunya dan bersatu dengan isterinya, sehingga Keduanya itu menjadi satu daging.

Efesus 5: 25, 28-30

(jephman.wordpress.com, March 24, 2008)

Regardless the polygamy issues, the comments from non-Muslim community are also expressed related to the basic principle and symbol Coptic Christian, Maria's religion, which is much exposed on Ayat-Ayat Cinta. In a way, it reveals the inaccuracy of the director and the novel author as the result of their ignorance of other faiths, but in another way it has been a media of interfaith dialogue to come to a better understanding. What is more, besides providing valuable information regarded to the symbol and religious practice, Non-Muslim's comments reveal their anxiety related to their position as minority and violent stereotype of Muslim.

..."The film represented the infidel Maria, meanwhile her cross is bleeding "powerless". If the film represented the infidel Aisha...

DINIKA, Volume I, Number 3, September - December 2016 
our church will be burnt out"....

..."Try to see from other perspectives...."

http://jephman.wordpress.com/2008/03/24/ayat-ayat-cinta/

I think this could be a breath of fresh air for the mission of preaching and introducing Islam. The author wrote the anxiety of Maria and her family if they accommodatee Naura at their home. There is an expression of how Maria's anxiety in helping the Muslim Naura presumed to be Christianization. Great. This writer seems to know very well the anxiety of some of us, Catholics, which often appear if we want to just help ease the burden of our fellow brothers and sisters who might by chance from the other religions. It seems that the writer has very extensive interactions, including with people who have different faiths from him. I watched the film once. Good though a lump. I think, Hanung Bramantyo did not do extensive research before making this film because there are some mistakes he did. First, in a scene depicted Maria embracing the Cross. For Muslims this is probably very reasonable because Maria is Coptic Christians. But here I need to inform you that Maria embraced the cross with the design of the Millennium Cross. It's weird. Millennium Cross Crusade is used by the Roman Catholic Church welcomes every turn of the Millennium (every 1000 years). The cross that Maria embraced is the cross with the design used by the Catholic Church throughout the year 2000. The cross was no longer in use today. The cross will be used again later in 3000 . The cross belongs to the Coptic Christians is far different from the shape of the Millennium cross. Second, in another scene, Maria is described in the table where there is a rosary. The rosary is a string of beads with a specific pattern that is used for prayer. Rosary is similar with beads for Muslims. Rosario is only owned by Catholics. Coptic Christians do not have this rosary. (gaulislam.com\%2Ffilmayat-ayat-cinta)

To conclude, the religious film label is embedded in Ayat-Ayat Cinta even though the director did not mention it. In regard to audience's expectancy and religious sentiment, its label attracts people's comments, either supporting or opposing the film. However, we cannot simplify the 
discourse around the film as fully contradicted sides since there are multi layers of audience's interpretation in negotiating the meaning of AyatAyat Cinta. In a way, Ayat-Ayat Cinta gets the benefit from its label as a preaching film. State apparatus supports the film since it is hoped to be as a mean of nation morality correction. Religious sentiment provides more motifs to watch it beyond its entertainment motif. On the other hand, religious sentiment also provokes extra burden to Ayat-Ayat Cinta since some elements seen contrasted to its dakwah spirit: Performa (cast), performance (acting), softening tone of storyline, polygamy issue, and expression of religious faith and practices. However, the dispute brings into further religious and cultural dialog, either with non-Muslim or among Muslim community themselves.

\section{Doa 3 Cinta}

Compared to Ayat-Ayat Cinta, 3 Doa 3 Cinta has less burden as religious film labeled even though it has similar background and Islamic message. Unlike Ayat-Ayat Cinta, people does not complain for "kissing scene" and "the openness" of 3 Doa 3 Cinta. Moreover, it turns to be an additional good point of the film as Sasono (old.rumahfilm.org/resensi/ resensi_3doa3cinta_2.htm) evaluated. By displaying "common issues" of Islam in daily life, the film does not depend on symbolic expression. Fahri, a protagonist of Ayat-Ayat Cinta, is depicted as an Islamic university student who is "almost perfect" in performing the strict Islamic value in daily life, especially in gender based relationship. Unlike Fahri, in 3 Doa 3 Cinta, Huda, a future leader of pesantren, is described as a common young man with his curiosity to a sexy dangdut singer, Dona Satelit. Thus, the image of familiar Islam in 3 Doa 3 Cinta has loosened the segregation between "Islamic" and "un-islamic" emblem because Islam is perceived as embedded culture in daily life which has no significant difference with others. The script writer and the director, Nurman Hakim, has created the 
familiarization of Islam by forming a chronic, a compilation of three main characters' life stories. Their life difficulty is common problems which can happen to anyone regardless their religion, for example young man's introduction to the sex. Nevertheless, Sasono also pointed out the lack of dramatic tension as the side effect of the simplicity of the story. In addition, Kadir (2009) considered the "openness" and Nurman's simplicity by telling the story of pesantren "as it is" has been as a market strategy of film producer in exploiting the negative side of pesantren and a kind of "self-orientalism" by "seeing themselves through the eyes of someone else".

Unlike Kadir, Irwansyah (2009) views that "the openness" of 3 Doa 3 Cinta is driven by close connection of Nurman's life background with the subject matter, pesantren. Based on his superior understanding on pesantren, Nurman's main intention is to record pesantren's life, to depict reality, the bad and good side of pesantren. The result "We saw santri falls sleep, got erection in the morning, polygamy of kyai, and phenomena of homosexuality in pesantren." Nevertheless, the simplicity of Nurman's intention does not mean a "save way" to talk about religion community in regard to long history of New Order repression on religion topic in SARA. ${ }^{2}$ In fact, in post- New Order era, the restriction of cinema censorship based on SARA code continues evidently limit media cultural expression as seen in censorship of 3Doa 3 Cinta. Even though 3 Doa 3 Cinta can be released with its "openness" manner in revealing pesantren life, the producer and director, Nan Achnas and Nurman Hakim, actually has complained about the censorship on the one of most significant part of the film:

2 The letters stand for Suku, Agama, Ras, Aliran. D avid Hill (2007, 45) writes that the code forbids broadcast of anything considered "seditious, insinuating, sensational, speculative, or likely to antagonist ethnic group, religious, racial or 'group' (class) tensions."

DINIKA, Volume I, Number 3, September - December 2016 
“The censors didn't realize it was an important part of the dialogue structure since it has a powerful influence on one of the characters. The dialogue comes just after the opening scene where Kyai Wahab tells them quite the opposite."

"Perhaps the censors did not watch the entire film, or perhaps they just don't understand film technique," Nan concluded. (The Jakarta Post, December 15, 2009)

Though the film has many themes and purposes, the emphasis of the main theme about the contestation of Islamic ideology is shown in the first part of the film that censored. The story begins with some preachings given by Kyai Wahab, a leader of the pesantren Al Hakim, where the santri are studying. Kyai Wahab says:

...It means "And the Jews will not be pleased with thee, nor will the Christians, till thou follow their creed." 3 But, it doesn't mean that we consider them as enemies. As long as they respect us and be kind to us, we should do the same."

In his preaching Kyai Wahab promotes respect and tolerance among religious adherents although he views the world from the perspectives we and they. By using three languages - Arabic, Javanese, and Indonesian - he localizes Islamic teaching, which is written in Arabic. In this way he comfortably speaks of universal religious values and fits them in with the Javanese value of harmony in life. His appearance also shows the characteristics of Indonesian Muslim attire. A contrast with Kyai Wahab's tolerance is shown in the appearance of the teacher of Sahid's militant Islamic group. The teacher's appearance is typically Middle Eastern: beard, gown, and turban. Conflict is also directly raised by the contrasts in the messages they preach

3 The complete verses in the Quran: And the Jews will not be pleased with thee, nor will the Christians, till thou follow their creed Say: Lo! the guidance of Allah (Himself) is Guidance. And if thou should follow their desires after the knowledge which hath come unto thee, then wouldst thou have from Allah no protecting friend nor helper. (Q.S. Albaqarah: 120). 
Israel and United States will always consider us as enemies. They will step their feet on us before we follow them. They've poisoned Moslems in many ways. They even kill Moslems in Palestine, Iraq, Afghanistan. That's why it's legitimate to (censor)... subhanallah.

Even though he speaks about the same text material as Kyai Wahab, his tone signifies that he is not on the same page. He highlights the conflicts of the world to raise the tension among religions. Furthermore, he uses religious sentiment to project hatred toward nation states, the United States and Israel, which are condemned for attacking Muslim countries, as a representation of Jewish and Christian powers. By looking at the other as a threat and enemy, he provokes hatred and legitimates violence against them as the way to defend his religion. Unlike Kyai Wahab, he only speaks in Indonesian and Arabic, not in Javanese. Thus, it can be interpreted that he is not originally from that area because it is more common in small areas of Java to speak in Javanese rather than in Indonesian, particularly in a public sermon. The director may use these techniques to contrast both of religious teachers referring the reality of ideology contestation. However, the national censorship boards perhaps consider that the word "blood" should be omitted because it may provoke image of violence of Islam. Therefore, instead of delivering the message of peace, it can be concerned as a highlighter of misinterpretation of Islam image as a religion of war.

On the other hand, the "openness" in 3 Doa 3 Cinta is considered successfully in delivering the complex motif of "sincere submission to Islam" which is closely misunderstood as terrorism by global stereotyping. As Sasono observed, sympathetically Nurman depicted poverty as the problem of Islamic society without being trapped to condemn it as the solely factor of radicalism. Related to the driven factor of radicalism act of Moslem, Sasono compares 3 Doa 3 Cinta with In The Name of God (Khuda Khay Liye), directed by Shooaib Manshoor, which told about a 
peace lover actress who turned to be a Taliban army to fight against US because of the political circumstances. Both 3 Doa 3 Cinta and In The Name of God converse the "sincere submission to Islam" in the global political tension which enforce innocent people to be a killer machine in the name of God. They did not cover up the fact of religion that has been a reason of violence act without overlooking the social, political, economical, and historical main background.

Moreover, the "openness" of 3 Doa 3 Cinta has broken up the dichotomy of Islam community by academician, such as santri, abangan, and priyayi as created by Clifford Geertz (1960); Islam modern and Islam traditional by Deliar Noer (1982); and Islam bourgeois and Islam proletariat by Nur Kholik Ridwan (2001). 3 Doa 3 Cinta shows the fluidity of santri identity as shown in the first scene in which the characters follow the Quran study in some pesantren which has different text interpretation. "I am wondered, does it mean that the characters experience social mobility?, From traditional into modern or from pluralist into scripturalist? From moderate into radical?" as Irwansyah (2009) observed. However, Kadir (2009) considered the differentiation as the marker of the dichotomy of Islam, particularly santri into radical, proletarian, and moderate Moslem. The typical of santri representated by Huda, Sahid, and Ryan is regarded as simplification of Islamic society realm by highlighting the contrast of one group compared to other groups and indifference to the fact that those groups are intertwined and dynamic in some ways. Thus, unlike Irwansyah, Kadir has a tendency to see that the characters are static; tramped in one category. Nevertheless, regarding to Huda's relationship with Dona Satelit, a dangdut singer, Kadir saw a borderless human desire between pesantren community and the world outside pesantren. This way, the grouping within Islam is applied more in term of religious teaching and practice rather than other humanity aspects. Furthermore, the intention of director to present the diversity of Muslim character can be interpreted as a highlighter of 
Muslim stereotyping.

Lastly, even though 3 Doa 3 Cinta carries the same baggage as Islamic film as Ayat-Ayat Cinta, it has less missionary spirit in term of Islamic glorification and Islamic way of prescription. Through it openness and simplicity, 3 Doa 3 Cinta is more intended to represent the diversity of Muslim in Indonesia by the awareness of the gap between doctrine and practice. However, the representation of theology has been a problem regarding to the violence image of Muslim as seen by a censored scene depicting a radical interpretation of a preacher. It can be considered that there is an effective attempt from the government, represented by national board censor, to conceal a reality of violence which is driven by religion interpretation. Since people's response to the textual representation has been concerned as a trigger of more conflicts, the government has doubted about maturity of people's religiosity. In addition, looking at traumatic experiences of religious-based violence, mass media are demanded to be convinced that Muslim is modern, tolerant, and fit with modern concerns (Hefner 2005, 388). Representation problem is also emerged by framing Muslim in particular types, such as radical, moderate, and proletariat, as depicted by the three main characters. On the other hand, as director intended, it can be interpreted as a representation of the plurality of Indonesian Muslim contrasting to single global image of Muslim which is dominated by Middle East figure as captured in AyatAyat Cinta. Furthermore, the characteristic of Indonesian Muslim with Javanese pesantren as its background is also revealed in Perempuan Berkalung Sorban.

\section{Perempuan Berkalung Sorban}

Compared to Ayat-Ayat Cinta and 3 Doa 3 Cinta, the representation of Perempuan Berkalung Sorban has attracted more public debate, even a constraint to boycott the film. Additionally, public dispute about the 
film has been a driven force for religion authorities to give a comment of the film which in return has been a magnet for further polemic. As Ali Mustafa Yakub, the head imam of Istiqlal, Jakarta's Grand Mosque, protested, there are two main objections of cons group: firstly, Perempuan Berkalung Sorban is condemned of representing bad image of pesantren and Islam, particularly the backwardness of pesantren and misrepresenting Islamic teaching as a source of violence against women. Unfortunately, most of religious leaders who oppose the film have not watched the film by themselves. They make their opinion merely based on public debate. In addition, negative opinion also comes from prominent figure of Islamic film makers such as Deddy Mizwar and Chaerul Umam (Imanjaya 2009). Deddy Mizwar, the chairman of National Film Council, states that the story of the film sees Islamic figh merely from a negative angle based on one sided interpretation. Similar to him, Chaerul Umam asses the unbalance representation of pesantren and kyai by showing merely the bad characters of them and put aside their positive ones. The bad representation of pesantren in Perempuan Berkalung Sorban also has been a reason for Misbach Yusa Biran to support Deddy Mizwar which caused the demand of the film revision (republika.co.id, February 07, 2009).

Furthermore, Fitriyani Aminudin, a lecturer at Universitas Islam Negeri (UIN) Syarif Hidayatullah Jakarta, considered the film, which is based on Abidah El Khalieqy's novel, as misinterpreting the Islamic teaching (republika.co.id, February 02, 2009). She highlighted a dialog that she mentioned, "No doubt, Alquran and Hadith prohibited a woman to go out without mubrim, even though for studying," Kiai Hanan to her daughter, Anissa. Fitriyani observes that the dialog had been repeated in some different scenes. Fitriyani, and Ali Mustafa Yakub, who are also the members of The Indonesian Ulema Council, insist that there is no verse of Alqur'an or Hadith which implies that message. In fact, as Ali mentioned, hadith told Muslim not to prohibit woman to go to mosque or 
studying. Another scene that Ali complained is the scene in which Annisa is riding a horse as her rebellion manifestation which implies the notion that Islam prohibits a Muslim woman to ride a horse. He reminds that it was opposite to the fact that in Prophet Muhammad's era there were many Muslim women rode horses.

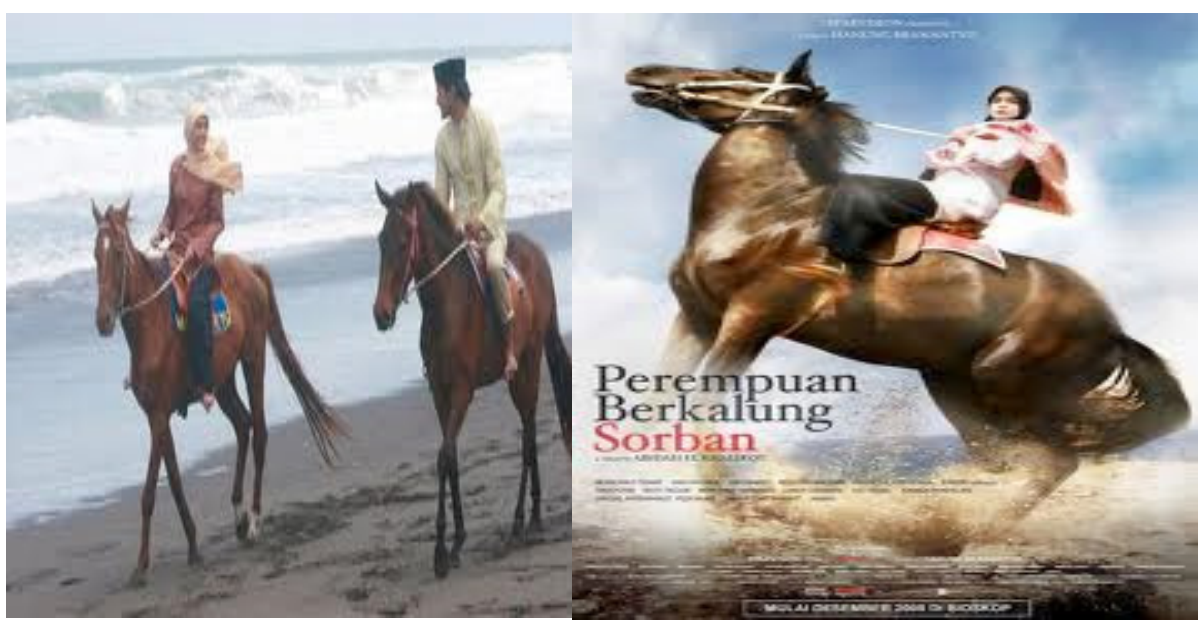

A scene and film poster in which Annisa Riding a Horse (http://www.google.com/images?)

Regarding to the representation of Muslim woman who is discriminated by religious leader in the name of religion-restriction in leadership, self-expression, and access to public area without her mubrim supervision-Umar Shihab, a leader of The Indonesian Ulema Council (MUI), asserts the significance of understanding the teaching based on the context. "Look at the context (when and where the event occurs in the film). If the film underestimates women, it is prohibited in Islam," Umar said" (Ciebal 2009). However, he admitted that in the past, the discrimination against women existed, but he neglected the reality that it still continues nowadays. Moreover, he is not sure whether MUI will ban Perempuan Berkalung Sorban because the council has not made any special effort to examine the film carefully. Unlike MUI, the Indonesian Board 
of Pesantren Cooperation (BKsPPI) firmly recommended to yank the film from the distribution based on national ijtima (congregation). As mentioned by its chairman, Didin Hafidhuddin, BKsPPI urges the government to ban Perempuan Berkalung Sorban because it displays bad image of pesantren in impeding women freedom, "Whatever the motivation of the film, in fact the screen forces into the corner pesantren. It describes pesantren as if it is a place where women santri imprisoned, violence against women's right, and husband treatment his wife unjustly." ${ }^{4}$ Another main objection, regarding to the image of pesantren, is identified with backwardness, particularly in the scene where the burning of Pramoedya Ananta Toer's book is regarded to his label as communist writer. The scene implies the reticence of pesantren to the modern ideology as Fitriyani asserts, "Whoever watches it, they will have a strong impression about the depiction of how unintelligent the santri who forbid communist books."

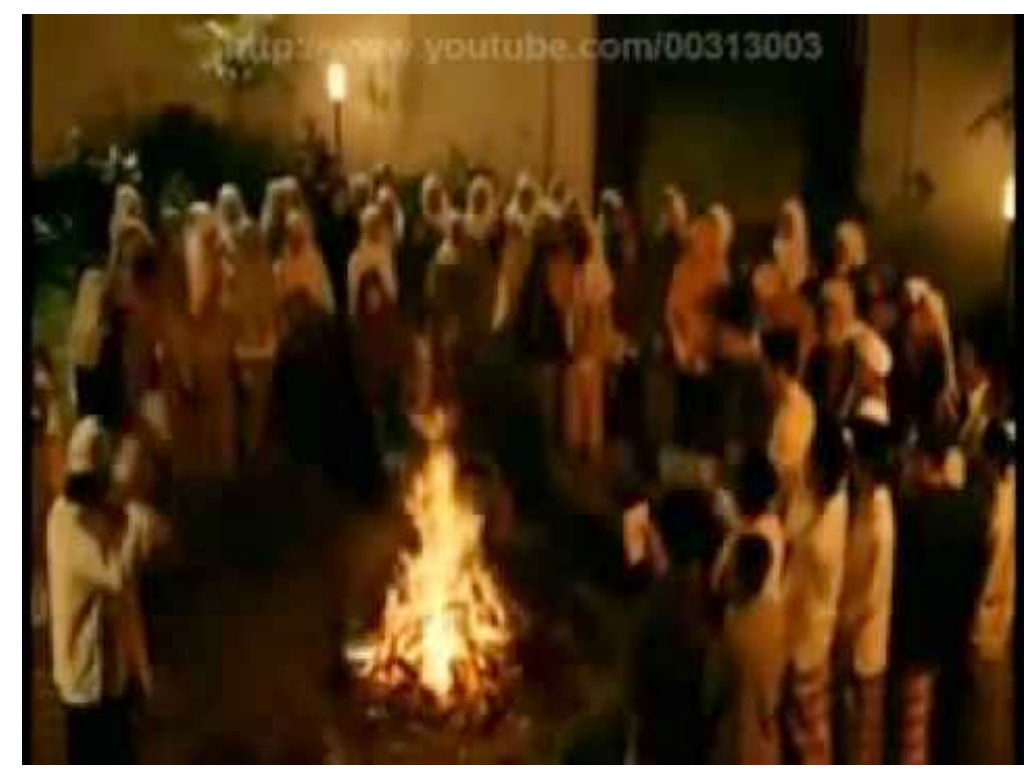

A scene of Pramoedya Ananta Toer's Book Burning (http://www.google.com/images?)

4 She/kpo, "BKsPPI: Tarik Peredaran Film 'PBS", February 12, 2009, www. republika.co.id.

DINIKA, Volume I, Number 3, September - December 2016 
On the other hand, reflected on Islamic group involvement in book banned, such as role of Front Pembela Islam (FPI) in Revolusi Agustus burning, (lenteradiatasbukit.blogspot.com, September 2009) people may consider the scene is reasonable. "I used to work in book store. Pramoedya's books would be burned by FPI members. In fact, those kinds of people are existed. It should be people like that that are banned, not the film!" a comment from an audience, so called deekk83, in Youtube (youtube.com, July 26, 2010). Similar comment given by so called suzzannamaniest. She emphasizes the significance of the scene to bring up the social reality, "It would not be a problem to point out the phenomena that public should know by a scene. However, Indonesian society has not ready yet to do this by considering that all the scenes are not in line with the reality, offensive to religion, uneducated, and misleading" (youtube.com, July 26, 2010). In addition, Fajar K. also concerns about the maturity of Indonesian Muslim to be open for a critique as intended by Perempuan Berkalung Sorban, "I believe Hanung does not mean to insult Islam, instead he asserts critique on Islamic teaching practice, which he thinks does not in line with the true spirit of Islam. In Western films, it is a common to despise a church which is considered unfaithful with Jesus teaching. Probably, Hanung was inspired by that such film. Nevertheless, as usual, Muslim shows overacting and disproportional responses, even to the efforts to humanize Islam," (indonesia.faithfreedom.org, February 08, 2009). In general, as Imanjaya observed, supporters of Perempuan Berkalung Sorban claims that the film is excellent because it criticizes practices against the true of Islamic teaching, particularly in revealing discrimination against woman (Imanjaya 2009). Meuthia Hatta Swasono, former State Minister for Women's Empowerment, contends that people criticize the film because they do not understand the problem of gap between the teaching and practice of Islam, "Women are abused often, meanwhile Islam does not discriminate women" (Imanjaya 2009) Furthermore, she illuminates, 
"There is a mistake in understanding Islamic teaching, Islamic value. I believe my religion teaches peace, virtue, and harmony. It is supposed to be like that. The film does not describe what Islam teaches." Therefore, she claims that the film represents the circumstances when Islamic teaching is misunderstood and not applied cautiously.

Reflected on the polarization of pro and cons of Perempuan Berkalung Sorban, Imanjaya (2009) discusses the film on the frame of ideology status and representation. Ideology related to the director's point of view on the film, meanwhile representation connected with what is seen in the film. On the first frame, he believes that from the director, there is no intention from Hanung to humiliate Islam through his film, instead of delivering his idealism. Imanjaya confirms Hanung's objective is not to criticize Islam, Alqur'an or hadith, but suggests self-critique to Muslim, particularly a tendency of a family in misusing sacred text to compel their demand to their children. Imanjaya highlights Hanung's statement that the main massage of the film is Islam guarantee the equality between male and female. In addition, Hanung declares that Perempuan Berkalung Sorban is his chance to respond people's complaints about polygamy issue in AyatAyat Cinta that is considered as an unfair representation for women based on patriarchy domination. Nevertheless, Imanjaya observed that instead of improving better representation of woman in Islam, the film describes the misogyny of Islam. Furthermore, Imanjaya wondered Hanung's stand point since Imanjaya cannot see Islam as a source of enlightenment rather than a basis of problem, "Why there is no indication implying liberating Islam in Perempuan Berkalung Sorban?" By making clear the distinction of Islamic and "un-Islamic" way, Imanjaya claims that Perempuan Berkalung Sorban tends to offer the solution in un-Islamic way, such as Bumi Manusia written by Pramoedya Ananta Toer, rather than suggest interpretation of gender and significant counter based on "a real" Islam. Therefore, in representation framework, Imanjaya considered that Perempuan 
Berkalung Sorban presents unfair image of Islam and pesantren since the negative images have not counteracted by their positive illustration. He admits that the film contains defense of Islam, but this element is not significant compares to the general image of how bad pesantren.

In short, the cinematic representation has been grounds of Perempuan Berkalung Sorban as one of the most controversials film in 2009. The cons group problematizes the representation of Islam and pesantren which are depicted as unintellect; backwardness, and a cause for discrimination against women. The pros side argues the importance of Perempuan Berkalung Sorban as a self-critic in Muslim community due the fact that the gap between Islamic teaching and its practice influenced by cultural, social, and political settings. Nevertheless, the emphasisze on misogynist text of Alqur'an and the absence of "Islamic way" as a resolution of the narrative has triggered accusation that the film is bias representation of Islam. Therefore, the label of Islamic film not only burdened the cinematic representation in term of how to conduct, but also ideologically "Islamic way".

\section{Conclusion}

The examination of audience's response on Ayat-Ayat Cinta, 3 Doa 3 Cinta, and Perempuan Berkalung Sorban illuminates the various impacts of Islamic film label embedded in their cinematic representation. On one hand, Islamic film can be a profitable trademark since it gives more reasons to attract audience more than entertainment motive. In addition, government with its religious politic project through its apparatus plays a significant role in supporting religious film as a part of construction of nation narration. On the other hand, government can be an obstacle for cinematic representation in the shadow of SARA policy. Furthermore, representation of religion analogue to religious teaching and practice creates religious film as media for religious dialogues between people, the 
government, the faith communities, and film makers. The interaction and intertwines among of them formulates film as a medium of "articulation of cultural exchange around presentation of the self" as Hoover (2003: 15) stated.

\section{References}

Geertz, Clifford. 1960. Religion of Java. Glen Coe: Free Press.

Hefner, Robert W. 2005. "Media Cetak Islam: Media Massa dan Persaingan Ideoplogis di Kalangan Muslim Indonesia.” In Media dan Citra Muslim: dari Spiritualitas untuk Berperang menuju Spiritualitas untuk Berdialog, ed. by Idi Subandy Ibrahim. Yogyakarta: Jalasutra.

Heider, Karl G. 1994. "National Cinema, National Culture: The Indonesian Case". In Colonialism, Nationalism in Asian Cinema, ed. by Wimal Dissanayake. Bloomington and Indiapolis: Indiana University Press.

Heryanto, Ariel. 2008. Popular Culture in Indonesia. USA and Canada: Routledge.

Hill, David T. 2007. The Press in New Order Indonesia. Jakarta and Kuala Lumpur: Equinox Publishing.

Hoover, Stewart. 2003. "Religion, Media and Identity: Theory and Method in Audience Research on Religion and Media". In Mediating Religion, ed. Jolyon Mitchell and Sophia Marriage. New York and London: T\&T Clark.

Imanjaya, Ekky. "Posisi Ideologis dan Representasi: Perempuan Berkalung Sorban, Membela atau Merusak Nama Islam?” http://old. rumahfilm.org/resensi/resensi_perempuanberkalungsorban.htm. Posted at February, 24, 2009. Accessed at June 20, 2010.

Irwansyah, Ade. "Nonton Film, Nonton (Islam) Indonesia. http://old. rumahfilm.org. Posted at January 20, 2009. Accessed at January 20, 2010.

Kadir, Hatib Abdul. 2009. "Filming Santri and Pesantren under the Post New Order Era”. Refleksi Journal of Sociology 12. 
Noer, Deliar. 1982. Gerakan Modern Islam di Indonesia. 1900-1942. Jakarta: LP3ES.

Nolan, Steve. 2003. "Towards a New Religious Film Criticism: Using Film to Understand Religious Identity Rather than Locate Cinematic Analogoe." In Mediating Religion, ed. Jolyon Mitchell and Sophia Marriage. New York and London: T\&T Clark.

Ridwan, Nur Kholik. 2001. Islam Borjuis dan Islam Proletar. Yogyakarta: Galang Press.

Salam, Aprinus and Ary Budiyanto. 2005. "Seni Bernuansa Islam PascaOrde Baru". Paper prented at Workshop on Art, Culture, Social and Political Change after Soeharto, at The University of Tasmania, Launcestone, Tasmania 16-18 December 2005.

Sasono, Eric. "Menonton Islam yang Akrab”. http://old.rumahfilm.org. Posted at January 20, 2009. Accessed at June 20, 2010.

Shirazy, Habiburahman El. 2004. Ayat-Ayat Cinta. Jakarta: Republika and Basmala. 